mention that it has no influence on the stated stability of the centre of visible direction. In the experiment with the gas-light, for instance, its remarkable change in apparent location is sufficiently accounted for by the changed relation of the corneal surface of refraction, and the stability of the visual centre is not more compromised than during cranial rotation.

Comparing, finally, my hypotheses relative to the binocular and monocular varieties of relief, I would attribute the superiority of the former variety to these several causes:-First, the interocular interval (binocular axle) being double the interval between the monocular and the encephalic centres at the binocular axle. Secondly, the duplicate perspectives in perfect binocular relief being dissimilar. Thirdly, ocular muscles only being engaged consentually during perfect binocular relief, so that their subservient perceptions are necessarily more vivid than those implied by the co-operation of cranial and ocular movements. Fourthly, the transference of the visual centre from eye to head in the binocular variety.

Guildford-street, Russell-square, W.C.

\section{COMPOUND DEPRESSED AND COMMINUTED FRACTURES OF SKULL; WOUND OF THE DURA MATER; TREPHINING; CURE.}

BY F. A. GRAY, L.R.C.P. LoND., M.R.C.S.E., MEDICAL SUPERINTENDENT, COTTAGE HOSPITAL, OTTERT ST. MARY.

ON Aug. 2nd, 188t, A. R-, aged five years, fell into a well between thirty and forty feet in depth. In endeavouring to get him out someone let the wooden cover of the well fall in, which struck him on the head. He was brought into the Cottage Hospital at Ottery St. Mary, a distance of three miles.

On admission at 4.30 P.Mr., he was in a state of collapse. Unconscious, pale, cold, almost pulseless, with pupils contracted. He had two wounds of the scalp, one beginning over the right eye and extending outwards and backwards over the head for a distance of about four inches. At the bottom of this wound could be seen two fractures of the skull running parallel to each other in the direction of the scalp wound and extending beyond it, the bone between the fractures being slightly depressed. The second wound was $\mathbf{Y}$-shaped, and situated near the summit of the head a little to the left of the middle line. Situated about the centre of this wound was a large irregularly star-shaped comminuted fracture of the skull depressed from a third to half an inch below the level of the surrounding bone. A lock of hair was jammed firmly between the fragments and could not be pulled out. The first described fracture did not seem to demand any special treatment; the wound in the scalp was brought together with some silver sutures and an absorbent pad applied. The other was left open pending his rallying from his collapsed state. At 9 'clock he had pretty well recovered from the collapse, the symptoms being more those of cerebral irritation. He lay on his side in a state of general flexion; breathing was not stertorous ; pupils not so much contracted as at first, and acting slightly to light. He looked semiconscious, but did not speak; could be roused a little, but seemed to resent any interference. Drank some milk put to his mouth in a feeding-cup. Temperature was $998^{\circ}$; pulse 120 . The nature of the fracture and the symptoms determined me to trephine and elevate or remove the fragments of bone. Mr. Duncan having administered chloroform, the wound in the scalp was extended backwards and the pericranium raised, the trephine being applied to the edge of sound bone. Rather more than a half-circle of bone was removed, the depressed bone raised, and nine fragments removed, the largest being nearly an inch long and half an inch wide. One narrow fragment half an inch long was driven vertically through the dura mater, and a clot of blood was distinctly visible around it under that membrane, and several fragments of the inner plate separated from the outer were pressing down on the brain. The wound in the scalp was brought together with silver sutures and an antiseptic absorbent pad applied. After the operation, and when the anrsthetic effects of the chloroform had passed off, he was quite conscious, talked, and was natural and happylooking. The temperature at midnight was $98^{\circ} 8^{\circ}$; pulse 112 .
Five grains of bromide of potassium were given, which he vomited. A second dose was given soon after, and was retained, as also were four grains of calomel.

Aug. 3rd. - $\mathrm{He}$ had slept well after the second dose of bromide; he complains of no headache; talks rationally, and plays with some toys. Bromide every four hours. Pulse 112, temperature $98^{\circ}$ in the morning. Pulse 112 temperature $982^{\circ}$ in the evening.-4th: Is going on well, and has slept. Temperature $98^{\circ}$; pulse 100 . The wounds are healing almost by first intention. Takes milk well.5th: Bowels acted after enema. Pulse 95 ; temperature $98^{\circ} 4^{\circ}$ From this date he went on well, and the temperature was not above normal except on one occasion, when a little pus was discovered under the scalp at the anterior part of the wound. A small scale of necrosed bone afterwards came away. He was discharged quite well on Sept. 26th.

Remarks.-The wisdom of trephining in cases of comminuted fracture like this one is exemplified by the result. The chances of recovery would have been small had the piece of bone been left sticking into the dura mater.

Ottery St. Mary.

\section{d a}

\section{HOSPITAL PRACTICE, BRITISH AND FOREIGN.}

Nulla autem est alia pro certo noscendi via, nisi quamplurimas et morborum et dissectionum historias, tum aliorum tum proprias collectas habere, et inter se comparare.-MorgagNI De Sed. et Caus. Morb., lib. iv. Proomium.

\section{G U Y'S HOSPITAL.}

SURGICAL CASES.

(Under the care of Mr. BRyant.)

WE publish three cases of injury to arteries of the lower extremity, which are of considerable interest. In the first case, as the result of a sprain, an aneurysm developed in the groin of a young and apparently healthy man, aged thirtythree, in whom there does not appear to have been any suspicion of atheroma of the vessels. In the other two cases severe contusion of the thigh was followed by occlusion of the main artery. Both of these recovered, although there was in one case the serious complication of suppuration in the knee-joint of the opposite side.

CASE 1. Inguinal Aneurysin (traumatic); Ligature of External Iliac Artery; Cure. (Reported by Mr. Burghard.)George E- aged thirty-three, a boiler-maker, was admitted into Job ward on Nov. 1st, 1884, under Mr. Bryant's care. Six months ago, when striking a blow, his foot slipped, and he strained himself a good deal. The next morning he noticed a small lump in his right groin, slightly towards the inner side. This has gradually increased in size, and latterly has given a good deal of pain. This pain is most acute below the swelling, and extends down the front of the thigh, and occasionally reaches the calf. The patient was a strong, healthy-looking man, and gave no history of syphilis. The tumour was in the line of the femoral artery, and was about the size of a small orange. Its longest diameter was parallel with Poupart's ligament. It pulsated synchronously with the heart, and over it with the stethoscope a slight bruit could be heard. The walls appeared to be very thin. The posterior tibial on the left side was more full than on the right; the dorsalis pedis of both sides was weak. The action of the heart was feeble. The apex bruit was normal; the second sound was rather indistinct. No other swelling about the body. Cold by means of Leiter's metallic coil was applied to the groin. Half an ounce of castor oil was given. Nov. 4th.--Under chloroform, the right groin having been shaved and raised by a pillow, an incision was made, beginning near the anterior superior iliac spine, and extended inwards and downwards for three inches and a half, the line of the incision being about one inch above the swelling. The muscular tissues were divided, and one small artery was twisted. The transversalis fascia was exposed with the peritoneum. The circumflex iliac vein was tied and divided. Two retractors were used to separate the edges of the wound. The sheath of the vessels was laid bare and torn through, exposing the external iliac artery. The aneurysin needle was 